\title{
Distinct inhibitory efficiency of siRNAs and DNAzymes to $\beta 1$ integrin subunit in blocking tumor growth
}

\author{
Magdalena Wiktorska1\#, Izabela Sacewicz-Hofman"\#, Olga Stasikowska-Kanicka², \\ Marian Danilewicz ${ }^{2}$ and Jolanta Niewiarowska1® \\ 1Department of Molecular and Medical Biophysics and 2Department of Nephropathology, Medical University of Lodz, Łódź, Poland
}

\begin{abstract}
Receptors of the $\beta 1$ integrin family are involved in many tumor-promoting activities. There are several approaches currently used to control integrin activity, and thus to potentially restrain tumor metastasis and angiogenesis. In this study, we compared inhibitory efficiencies of siRNA and DNAzymes against the $\beta 1$ integrin subunit (DE $\beta 1)$, in a mouse xenograft model. Both inhibitors were used under their most favorable conditions, in terms of concentrations, incubation time and lack of cytotoxic effects. Transfection of siRNA $\beta 1$ or DE $\beta 1$ remarkably inhibited the growth of both PC3 and HT29 colon cancer cells in vitro, and decreased their capability of initiating tumor formation in the mouse xenograft model. siRNA $\beta 1$ appeared to be slightly more efficient than $D E \beta 1$ when tested in vitro, however it was comparably less proficient in blocking the tumor growth in vivo. We conclude the DNAzyme, due to its greater resistance to degradation in extra- and intracellular compartments, to be a superior inhibitor of tumor growth in long lasting experiments in vivo when compared to siRNA, while the latter seems to be more efficient in blocking $\beta 1$ expression during in vitro experiments using cell cultures.
\end{abstract}

Key words: tumor growth; tumor angiogenesis; $\beta 1$ integrins; adhesion; invasiveness

Received: 02 October, 2012; revised: 30 December, 2012; accepted: 12 February, 2013; available on-line: 19 March, 2013

\section{INTRODUCTION}

Adhesion molecules such as integrins, mediate direct cell-cell recognition and cell-matrix interactions (Hynes, 1992), which are essential for tumor cell migration (Holly et al., 2000) and basement membrane penetration (Uhm et al., 1999). Although integrins have become attractive therapeutic targets (Albelda, 1993), there are contrasting results on integrin expression patterns in different tumor types, making it difficult to draw general conclusions on their role in metastasis. Transformed cancer cells are often characterized either by the loss/reduction or increase of integrin expression (Pignatelli et al., 1991; Zutter et al., 1990). Furthermore, tumor progression and metastasis are associated with changes in a numerous integrin signaling cascades eliciting various cell functions, such as morphological changes, adhesion, migration and gene activation, which are all relevant to the metastatic cascade.

There are several approaches currently used to downregulate the integrin activity, and thus to restrain tumor metastasis and angiogenesis. Up until now, the most advanced studies researched the blockade of integrin interaction with an extracellular matrix. They chiefly focus on the applications of monoclonal antibodies, small-molecule peptides, and peptidemimetics (Ma \& Adjei, 2009; Yazji et al., 2007). Another group of approaches is based on gene-silencing methods, in which compounds that function with sequence-specificity at a post-transcriptional level are used. Among them, the most intensively studied compound is the small interfering RNA (siRNA), which has recently been developed as a powerful tool to suppress the expression of specific gene products (Schiffelers et al., 2004; Kohlgraf et al., 2003; Mukherjee et al., 2005; Ren et al., 2004). This technique was successfully used to explore its potential therapeutic values (Hannon, 2002). A different approach is represented by DNAzymes, which recently have emerged as a new class of nucleic acid-based gene-silencing agents (Isaka, 2007). DNAzymes are single-stranded DNA catalysts, which cleave the target at predetermined phosphodiester linkages (Schubert et al., 2003). Due to the low cost of synthesis, high stability and flexible rational design features, DNAzymes have been demonstrated to be a potential new class of drugs inhibiting gene expression (Schubert \& Kurreck, 2004; Cieslak, 2002; Cieslak, 2003; Manes et al., 2003).

In this report, we compared the capability of siRNA and DNAzymes to inhibit the expression of $\beta 1$ integrins in colon adenocarcinoma (HT29) and prostate (PC3) cancer cells. The reason for which we targeted the $\beta 1$ subunit is because this integrin family includes twelve members, thus this method has a broad-spectrum antiintegrin effect (Goel et al., 2005; Niewiarowska et al., 2009). Although both inhibitors were aimed at the same target, the mechanisms by which they caused the degradation of mRNA were different.

\section{MATERIALS AND METHODS}

siRNA to $\beta 1$ mRNA. Unmodified sequences of siRNA to $\beta 1$ mRNA were synthesized by Thermo Scientific Dharmacon RNAi Technologies (Denver, CO, USA). The following siRNAs were used: (1) sense CGG AGG AAG UAG AGG UUA UUU; antisense AUA ACC UCA ACU UCC UCC GUU; (2) sense CCA CAG ACA UUU ACA UUA AUU; antisense UUA AUG UAA AUG UCU GUG GUU; (3) sense GGU AGA AAG UCG GGA CAA AUU; antisense UUU GUC CCG ACU UUC UAC CUU; (4) sense CAA GAG

e-mail: jolanta.niewiarowska@umed.lodz.pl

Abbreviations: siRNA $\beta 1$, siRNA to $\beta 1$ integrin $m R N A ; ~ s i R N A_{c}$ scrambled sequences; hDE $\beta 1$, DNAzyme to human $\beta 1$ mRNA; $\mathrm{hDE}_{c}$, scrambled human form of DNAzyme; $\mathrm{mDE} \beta 1$, DNAzyme to murine $\beta 1$ mRNA; $\mathrm{mDE}_{c}$, scrambled murine form of DNAzyme 
AGC UGA AGA CUA UUU; antisense AUA GUC UUC AGC UCU CUU GUU. The scrambled sequence of siRNA was designed and synthesized by Thermo Scientific Dharmacon RNAi Technologies.

DNAzyme to $\beta 1$ mRNA. DNAzyme to human $\beta 1$ mRNA (hDEß1, 5' CAAGGTGAGg $\mathrm{g}_{2} \mathrm{c}_{3} \mathrm{t}_{4} \mathrm{a}_{5} \mathrm{~g}_{6} \mathrm{c}_{7} \mathrm{t}_{8}$ $a_{9} c_{10} a_{11} a_{12} c_{13} g_{14} a_{15}$ AATAGAAG 3') was synthesized and analyzed as previously described (Cieslak et al., 2002; Wiktorska et al., 2010). 2'-O-methyl analog of h $\beta 1 \mathrm{DE}$ and inactive human DNAzyme $\left(\mathrm{hDE}_{\mathrm{C}}\right.$, 5' T'TCT'TATAg $g_{2} c_{3} t_{4} a_{5} g_{6} c_{7} t_{8} a_{9} c_{10} a_{11} a_{12} c_{13} g_{14} a_{15}$ TCT'T'TGGAG 3') were used throughout this work. For in vivo tests 2'-O-methyl DNAzymes to the murine $\beta 1$ integrin subunit were designed and synthesized, both in an active (mDE $\beta 1,5^{\prime}$ CAAGGTGAGg $\mathrm{g}_{2} \mathrm{c}_{3} \mathrm{t}_{4} \mathrm{a}_{5} \mathrm{~g}_{6} \mathrm{c}_{7} \mathrm{t}_{8} \mathrm{a}_{9} \mathrm{c}_{10} \mathrm{a}_{11} \mathrm{a}_{12} \mathrm{c}_{13} \mathrm{~g}_{14} \mathrm{a}_{15}$ AAT'TGAAG 3') and scrambled form (mDEc, 5' GCGAAGTGAg $\mathrm{g}_{2} \mathrm{c}_{3} \mathrm{t}_{4} \mathrm{a}_{5} \mathrm{~g}_{6}$ $c_{7} t_{8} a_{9} c_{10} a_{11} a_{12} c_{13} g_{14} a_{15}$ GTAAAGUA 3') (Niewiarowska et al., 2009). All DNAzymes were purified by HPLC and ion exchange chromatography (to $98 \%$ ). Their purity was examined by PAGE under denaturing conditions (IDT, Coralville, IA, USA).

Carcinoma cell lines and culture conditions. The human colon adenocarcinoma cell line HT29, was obtained from Ludwik Hirszfeld Institute of Immunology and Experimental Therapy (Polish Academy of Sciences, Wroclaw, Poland). The human prostate carcinoma cell line PC3, was obtained from ATCC company (American Type Culture Collection, Manassas, VA, USA). HT29 and PC3 cells were cultured as described previously (Wiktorska et al., 2010). For the experiments with siRNA, cells were transferred to 6-well dishes and used at $70 \%$ confluence in the MEM- $\alpha$ (HT29) or F-12K (PC3) full medium without antibiotic. LipofectAMINETM Reagent $(5 \mu \mathrm{g} / \mathrm{ml})$ was diluted in Opti-MEM reduced medium (GIBCO BRL, Invitrogen, Carlsbad, CA, USA) containing $5 \mathrm{mM} \mathrm{MgCl}$ and joined with a mixture of all four siRNAs diluted with the same medium to obtain the final concentration of $60 \mathrm{nM}$. After a $24 \mathrm{~h}$ incubation, the medium was exchanged for one containing antibiotics. $48 \mathrm{~h}$ post-transfection cells were detached with trypsin/EDTA. Subsequently, DNAzymes were mixed with LipofectAMINE ${ }^{\text {TM }}$ Reagent $(5 \mu \mathrm{g} / \mathrm{ml}$ ) and suspended in Opti-MEM-reduced medium containing $5 \mathrm{mM} \mathrm{MgCl}_{2}$ to obtain a final concentration of $1 \mu \mathrm{M}$. Transfection was performed for $6 \mathrm{~h}$ according to the manufacturer's protocol. After a $12 \mathrm{~h}$ incubation in a corresponding medium supplemented with $10 \%$ FBS, cells were detached with trypsin/EDTA and used for experiments. Cell viability was determined microscopically by trypan blue exclusion and only cell cultures having less than $1 \%$ of dead cells were included in the study.

Animals. Six- to eight-weeks-old BALB/cA nude (nu-/-)-B6.Cg-Foxn1nu mice (Mus musculus) were purchased from Taconic Europe, Ejby, Denmark. Mice were housed under pathogen-free conditions in microisolator cages with laboratory chow and water available ad libitum. For the experiments animals were divided into three groups (each group $n=5$ ), anesthetized before any invasive procedures, and placed under observation until fully recovered. All experiments and procedures were reviewed by the Local Ethical Committee and performed in accordance with the EU regulations regarding the humane care and use of laboratory animals.

Western blotting. Subconfluent cells were washed with PBS and lysed in Mammalian Protein Extraction Reagent (M-PER, PIERCE, Rockford, IL, USA) supplemented with protein inhibitor cocktail (Roche, Basel, Switzerland). In all, $30 \mu \mathrm{g}$ samples of total protein from cells mock-transfected or transfected with siRNA or
DNAzymes were treated as previously (Wiktorska et al., 2010). The membrane was incubated with rabbit polyclonal anti-human $\beta 1$ integrin subunit antibodies (Santa Cruz Biotechnology, Santa Cruz, CA, USA) and then the level of $\beta$-actin was detected with rabbit polyclonal antibody (Abcam, Cambridge, MA, USA).

Flow cytometry. Harvested cells were washed with serum-free appropriate medium. Cells $\left(1 \times 10^{5}\right)$ suspended in a medium containing $1 \%$ bovine serum albumin were incubated in the dark at $4^{\circ} \mathrm{C}$ for $30 \mathrm{~min}$ with fluorescein isothiocyanate-conjugated monoclonal antibodies against the $\beta 1$ subunit $(0.1 \mu \mathrm{g} / \mathrm{ml})$ (DAKO A/S, Denmark). After being washed and fixed with $1 \%$ paraformaldehyde/PBS, cell fluorescence was measured with a FACScan flow cytometer (Becton Dickinson, Mountain View, CA, USA). The results were analyzed with PC Lysis II software.

Adhesion assay. Maxisorp loose Nunc-Immuno ${ }^{\mathrm{TM}}$ modules (Pittsburgh, PA, USA) were coated for $2 \mathrm{~h}$ with $100 \mu \mathrm{l}$ of fibronectin or collagen type I at $10 \mu \mathrm{g} / \mathrm{ml} /$ TBS. Next wells were washed and blocked for $1.5 \mathrm{~h}$ at $37^{\circ} \mathrm{C}$ in a humidified $5 \% \mathrm{CO}_{2}$ atmosphere with $200 \mu \mathrm{l}$ of $1 \% \mathrm{BSA} / \mathrm{TBS}(0.1 \mathrm{mM} \mathrm{CaCl}, 1 \mathrm{mM} \mathrm{MnCl})$. Cells were then added at $1 \times 10^{5}$ cells $/ 0.1 \mathrm{ml}$ of appropriate medium for $1.5 \mathrm{~h}$. The total cell-associated protein was determined by dissolving the attached cells in $200 \mu \mathrm{l}$ of BCA protein assay reagent directly in the microtiter wells (PIERCE, Waltham, MA, USA). The absorbance was determined at $562 \mathrm{~nm}$ (BioKinetics Reader EL340, BioTek Instruments, Winooski, VT, USA).

Chemoinvasion assay. Assays were performed as described previously (Wiktorska et al., 2010). The upper chambers were coated with Matrigel ${ }^{\mathrm{TM}}$ (35 $\mu \mathrm{g} /$ filter) (Becton Dickinson, Bedford, MA, USA) and $50 \mu \mathrm{l}$ of cell suspension $\left(2 \times 10^{6}\right)$ in either MEM- $\alpha$ or F-12K with $0.1 \%$ BSA added to the upper chamber. Conditioned medium (a source of chemoattractants) was obtained by incubating mouse fibroblasts (NIH 3T3) for $24 \mathrm{~h}$ in serum-free DMEM medium in the presence of ascorbate (50 $\mathrm{mg} / \mathrm{ml}$ ).

Mouse tumor model. Tumor xenograft model was performed as described before with a modification (Niewiarowska et al., 2009). HT29 or PC3 cells were established by s.c. injection of $2 \times 10^{6}$ cells mixed with Matrigel $^{\mathrm{TM}}$ at the ratio of $1: 1$ into female $(n=20)$ or male $(n=20)$ BALB/cA nude (nu-/-)-B6.Cg-Foxn $1^{n u}$ mice, respectively. When tumors reached the volume of $80-150 \mathrm{~mm}^{3}$, mice were divided into two groups. Specimens of the first group received an injection of $0.5 \mathrm{nmol}$ mixed siRNAs $(1.67 \mu \mathrm{g}$ each one per tumor), while the specimens of the second one were injected with $6.67 \mathrm{mg}$ of siRNA ${ }_{C}$ per tumor 8 times every second day. In parallel, when DNAzymes were used, mice were also divided into two groups: the first one received an injection of $1.25 \mu \mathrm{gDE} \beta 1$, and the second one of $1.25 \mu \mathrm{g} \mathrm{mDE}_{\mathrm{C}}$ per tumor 8 times every second day. Tumors were measured three times a week and their volumes were calculated by the formula $\left[\pi / 6\left(w_{1} \times w_{2} \times w_{3}\right)\right]$. Tumor specimens were fixed in $4 \%$ buffered formaldehyde and were routinely processed for paraffin embedding.

Immunohistochemistry. Paraffin sections were incubated overnight at $4^{\circ} \mathrm{C}$ with rat monoclonal anti CD34 (MEC 14.7; Abcam, Cambridge, MA) at a dilution of $1: 100$. Afterwards, the polyclonal rabbit anti-rat immunoglobulins/HRP (P0450; DakoCytomation, Glostrup, Denmark) were used. Visualization was performed by incubating the sections in a 3.3'-diaminobenzidine solution (DakoCytomation, Glostrup, Denmark). For each sample a negative control was processed. The microvessels were 

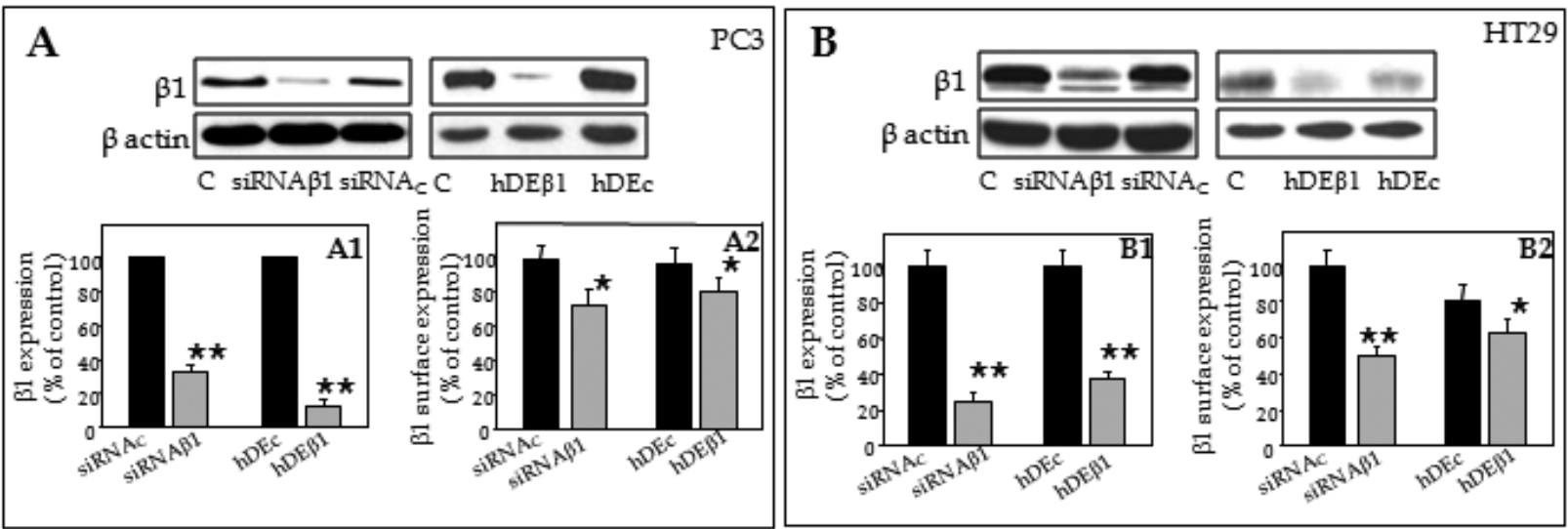

Figure 1. Inhibition of $\beta 1$ integrin synthesis in $\mathrm{PC} 3$ and $\mathrm{HT} 29$ cells.

PC3 and HT29 cells were incubated with siRNA $\beta 1$ or siRNA $A_{C}\left(1.67 \mu \mathrm{g}\right.$ each) for $48 \mathrm{~h}$, and with hDE $\beta 1$ or hDE $\mathrm{C}_{c}(1.25 \mu \mathrm{g}$ each) for $18 \mathrm{~h}$. Then, the $\beta 1$ level was measured by Western immunoblotting. Protein bands were scanned, and data presented as the mean \pm S.D. was calculated from three separate experiments (A1, B1). Surface expression of $\beta 1$ integrin subunit in PC3 (A2) and HT29 cells (B2) was analyzed by FACS. It was influenced and decreased by both inhibitors compared to control. $\left({ }^{*} P<0.05 ;{ }^{* *} P<0.001\right)$. Data are expressed as $\%$ of the control untreated PC3 or HT29 cells.

determined by counting all CD34-positive structures (MultiScan 8.08 software, Computer Scanning Systems, Poland) in a sequence of 10-15 consecutive computer images of $250 \times$ high power fields of $0.047914 \mathrm{~mm}^{2}$ each. The mean values of microvessels with or without lumen were calculated per $\mathrm{mm}^{2}$.
PC3
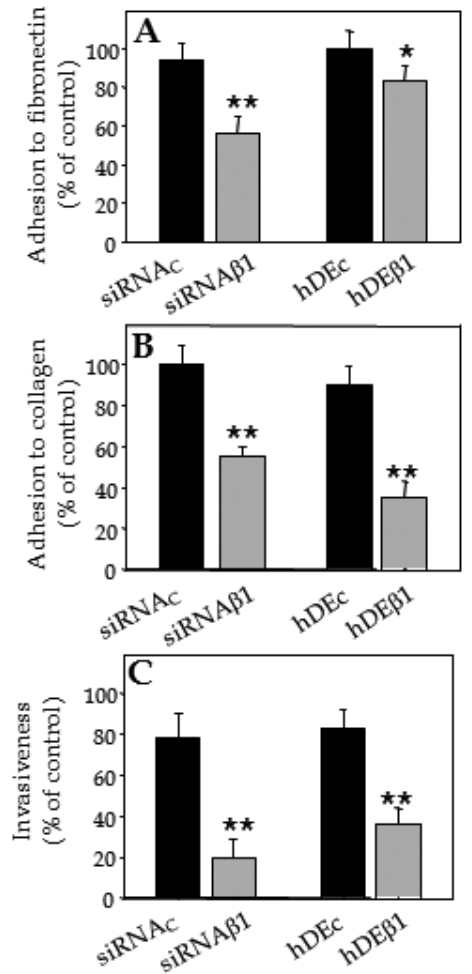

HT29
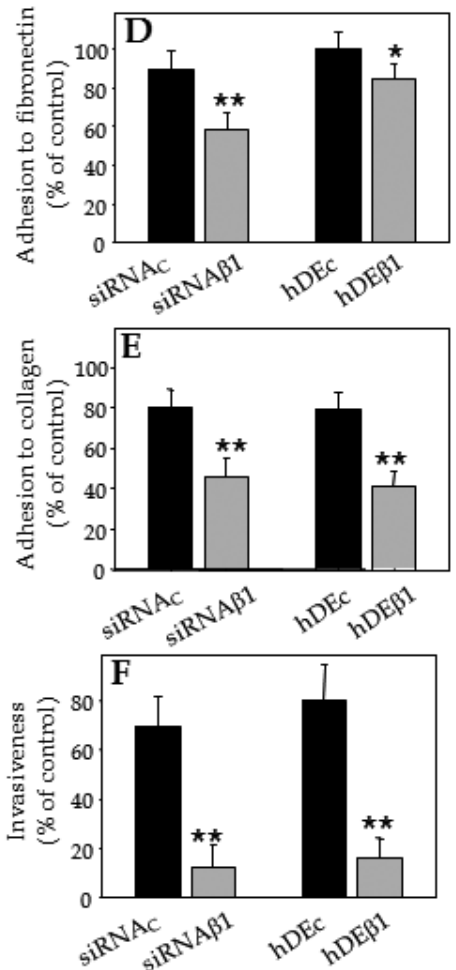

Figure 2. Effects of siRNA $\beta 1$ and $D E \beta 1$ on cell adhesion and invasiveness. The adhesion of PC3 (A, B) or HT29 (D, E) after transfection with siRNA 31 (6.67 $\mu \mathrm{g})$ and $\mathrm{hDE} \beta 1(1.25 \mu \mathrm{g})$ was evaluated using plastic wells coated with fibronectin (A, D) or collagen (B, E). The level of adhesion was determined and compared with that of control cells. $\mathbf{C}$ and $\mathbf{F}$ show the effects of siRNA 1 and hDE $\beta 1$ on invasive properties of PC3 and HT29. Treated cancer cells were allowed to invade Matrigel ${ }^{T M}$ and migrate into the lower part of the filter. The number of invasive cells was expressed in relation to control cells treated with lipofectamine only.
Data analysis. All values are expressed as mean \pm S.D. and were compared with controls. Significant difference was taken for $P$ values less than 0.05 .

\section{RESULTS}

Inhibition of cancer cell adhesion and invasiveness

Before comparing the efficiency of siRNA 1 and hDE 1 to inhibit adhesive and tumorogenic properties of cancer cells, we evaluated their effect on the $\beta 1$ expression in PC3 and HT29 cells in preliminary experiments. Incubation of cells with siRNA $\beta 1$ and hDE $\beta 1$ for 48 and $18 \mathrm{~h}$ respectively, specifically inhibited synthesis of the $\beta 1$ in both types of cells. A quantitative analysis of the $\beta 1$ by densitometry revealed a significant $(P<0.001)$ decrease in the $\beta 1$ protein in both types of cells transfected either with siRNA $\beta 1$ or hDE $\beta 1$ when compared to controls (Figs. 1A1, B1). The $\beta$-actin expression was unaffected neither by the controls nor the siRNA $\beta 1$ or $h \beta 1 D E$, indicating that non-specific downregulation of protein expression did not occur and equal quantities of protein were loaded. Under these conditions, both agents significantly reduced the $\beta 1$ integrin subunit expression on the surface of PC3 and HT29 cells when compared to controls $(P<0.05)$, as detected by flow cytometry (Figs. 1A2, B2). Both agents were used under their most favorable conditions, in terms of concentrations and incubation times. Such settings, although different, were optimal to bring about the most advanced inhibition of the $\beta 1$ expression with no cytotoxic effects observed.

Treatment of PC3 and HT29 cells with siRNA 11 and $\mathrm{hDE} \beta 1$ resulted in a significant inhibition of adhesion to fibronectin and collagen type I (Fig. 2). In this assay cell adhesion to either fibronectin or col- 

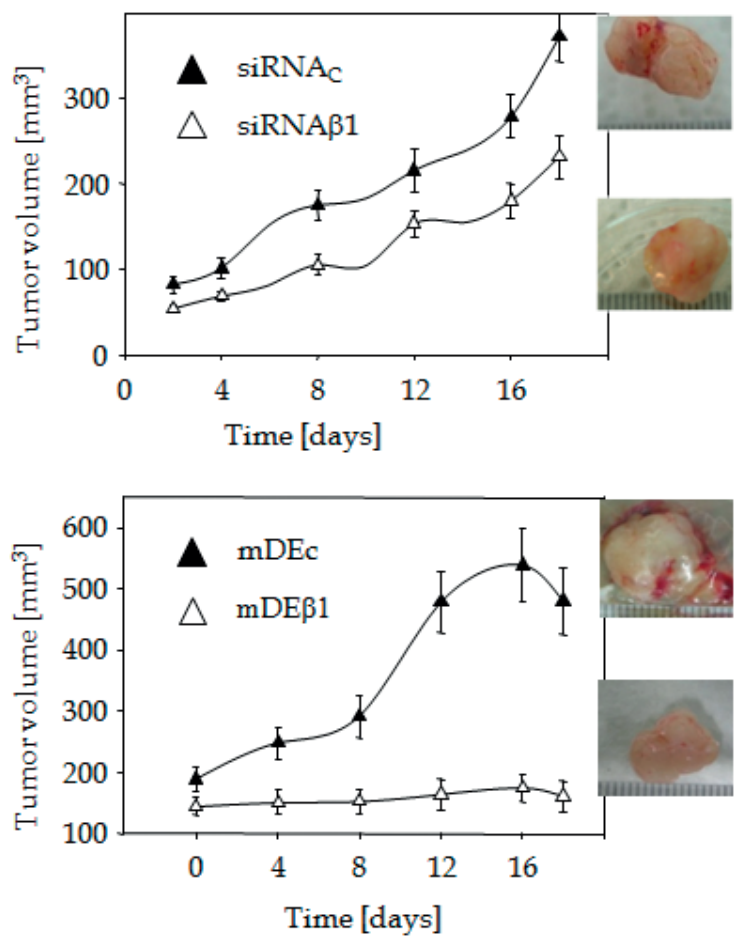

C

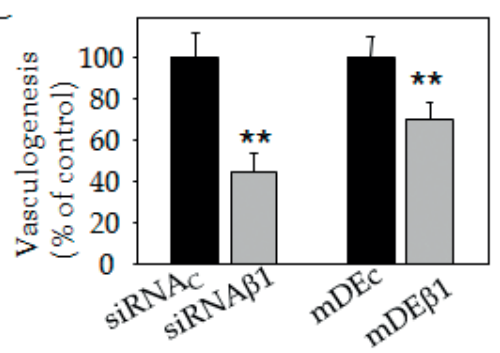

Figure 3. Effects of siRNA $\beta 1$ and $D E \beta 1$ on tumor growth of human prostate carcinoma xenografts.

PC3 cells were injected into male BALB/CA nude mice $(n=20)$ to develop solid tumors. Then, mice were divided into 4 groups ( $n=$ 5 ) and treated intratumorally 8 times every second day with the following dosages: 1) siRNAß1 (6.67 $\mu \mathrm{g}$ siRNA $=1.67 \mu \mathrm{g}$ siRNA $\left.{ }_{1-4}\right)$; 2) $\operatorname{siRNA}_{c}(6.67 \mu \mathrm{g})$; 3) $\mathrm{mDE} \beta 1(1.25 \mu \mathrm{g})$; 4) $\mathrm{mDE}_{\mathrm{c}}(1.25 \mu \mathrm{g})$. Both siRNA $\beta 1$ and $\mathrm{mDE} \beta 1$ significantly reduced the volume of the carcinoma tumor $(\mathbf{A}, \mathbf{B})$. In both panels, inserts show tumors after administering control with siRNA $A_{c}$ or $\mathrm{mDE}_{c}$ and siRNA $\beta 1$ or $m D E \beta 1$. Panel $C$ shows the quantification of microvessels stained for CD34 in cross sections of vehicles, control siRNA or DE and siRNA $\beta 1$ or mDE $\beta 1$ treated PC3 tumors. ${ }^{* *} P<0.01$.

lagen was analyzed for $1.5 \mathrm{~h}$ at $37^{\circ} \mathrm{C}$ (Figs. 2A, B, D, $\mathrm{E})$. The extent of adhesion was evaluated based on the amounts of cellular protein detected as associated with wells. siRNA $\beta 1$ consistently inhibited the adhesion of both cell types to either fibronectin or collagen by $50-$ $55 \%$. hDE $\beta 1$ was less efficient in blocking adhesion to fibronectin. It produced similar inhibition to siRNA $\beta 1$ when adhesion of cells was tested to collagen.

To evaluate the effect of both inhibitors on cell invasion, transwell invasion assays were carried out. Transfection drastically reduced the number of PC3 or HT29 cells that invaded through the Matrigel ${ }^{\mathrm{TM}}$-coated membrane when compared to untreated cells. (Fig. 2C, F). Downregulation of $\beta 1$ integrins in these cells led to similar decrease in the number of invading cells, namely by
65 to $80 \%$, pointing out no significant difference in the inhibitory efficiency between both used inhibitors.

\section{Inhibition of tumor growth}

To compare the anti-tumor activity of siRNA $\beta 1$ and mDEß1 in vivo we established human PC3 cell xenografts in male BALB/cA nude $\left(\mathrm{nu}^{-/-}\right)-\mathrm{B} 6 . \mathrm{Cg}-\mathrm{Foxn} 1 \mathrm{nu}$ mice. Then, $6.67 \mu \mathrm{g}$ siRNA $\beta 1$ or $\mathrm{mDE} \beta 1$ at $1.25 \mu \mathrm{g}$ per injection, either active or control, were administered into solid PC3 tumors every second day after the tumor volume was assessed to be $80-150 \mathrm{~mm}^{3}$. Fig. 3A shows that solid prostate carcinoma growth is considerably inhibited by siRNA when compared with control. When mDE $\beta 1$ was used in the same model, the tumor growth was almost entirely congested (Fig. 3B). To quantify blood vessels in PC3 tumors from control and siRNA $\beta 1$ - or mDEß1-animals, tissue sections were stained immunochemically with monoclonal antibody to CD34. Immunostaining demonstrated both blood vessels with wide lumen and with markedly narrowed lumen located within tumor stroma. Treatment caused a statistically significant decrease $(P<0.01)$ in the number of CD34-positive tumor blood vessels when compared with relevant controls (Fig. 3C). Microscopic evaluation revealed that in siRNA $\beta 1$ - or mDE $\beta 1$-treated tumors the vascular stroma was scant, and that large areas of tumor cells underwent ischemic necrosis (not shown).

Figure 4 shows that mDE $\beta 1$ also blocked the tumor growth of human colon adenocarcinoma more efficiently than siRNA $\beta 1$. In these experiments PC3 cells were substituted by HT29 cells to develop solid tumors in female $\mathrm{BALB} / \mathrm{cA}$ nude mice. All experiments were performed exactly as described above. When administered intratumorally, the siRNA or DE showed a direct inhibition of colon solid tumor growth by targeting the $\beta 1$ integrins. Also, in this system, there was a significant reduction in the number of blood vessels in the HT29 tumors treated with siRNA $\beta 1$ or $\mathrm{m} \beta 1 \mathrm{DE}$ compared with the control tumors $(P<0.01)$.

\section{DISCUSSION}

Several reports showed that $\beta 1$ integrins contribute to tumor progression through their participation in signaling events that control such functions as migration, proliferation, survival, invasion, and angiogenesis (Rathinam $\&$ Alahari, 2010). The $\beta 1$ integrins, particularly $\alpha 2 \beta 1$ and a5 $\beta 1$, promote tumor growth in vivo and are uniquely required in cancer cells for localization, expression, and functioning of the insulin-like growth factor type 1 receptor (IGF-IR), which is known to support cancer cell proliferation and survival (Goel et al., 2005). The mechanism proposed for the $\beta 1$ integrin controlling the IGFIR activity involves the recruitment of specific adaptors to the plasma membrane by the $\beta 1$ and increasing their concentration proximal to the growth factor receptor (Goel et al., 2004).

In our experimental setting, in order to reduce the expression of integrins, we used inhibitory nucleic acids, which cannot work as agonists. To knock down the $\beta 1$ integrin synthesis two approaches were used and their inhibitory efficiency in anti-tumor activity was compared. The first one utilized DNAzymes, a novel class of antisense molecules. The 10-23 DNAzymes belong to a group of RNA-cleaving DNA molecules that contain a catalytic domain and cleave the RNA sequence at a phosphodiester bond between an unpaired purine and a 

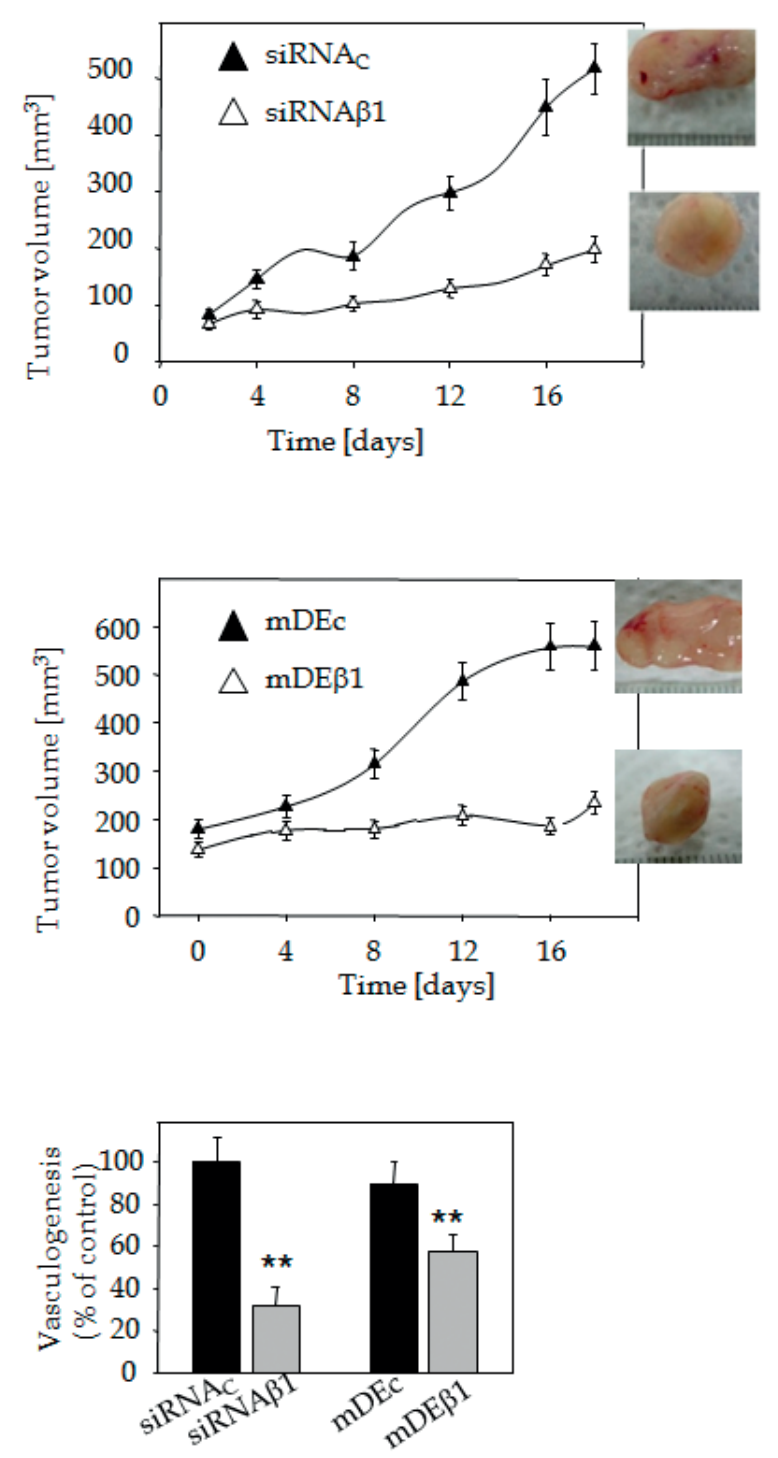

Figure 4. Effects of siRNA $\beta 1$ and $D E \beta 1$ on tumor growth of human colon cancer xenografts.

HT29 cells were injected into female BALB/CA nude mice to develop solid tumors. The experiment was performed as described in Fig. 3. Both siRNA $\beta 1$ and $\mathrm{mDE} \beta 1$ significantly reduced the volume of the adenocarcinoma tumor (A, B). In both panels inserts show tumors after administering siRNAc or mDEc, and siRNA $\beta 1$ or $\mathrm{mDE} \beta 1$. Panel $\mathrm{C}$ shows the quantification of CD34 positive microvessels with lumen in HT29 tumor cross sections. ${ }^{*} P<0.01$.

paired pyrimidine residue (Santoro \& Joyce; 1998 Silverman, 2005; Tritz et al., 2005). In our previous studies we observed that unmodified DNAzymes were rapidly degraded in cells. Therefore, to avoid the degradation in present studies we used their O-Metyl analogs (Cieslak et al., 2003).

The 10-23 DNAzymes targeting GATA-3 mRNA have recently been developed and their anti-asthmatic effect in mouse models has been successfully demonstrated (Sel et al. 2008). Since GATA-3 plays a central role in Th2 cell differentiation (Barnes, 2008) and in promoting Th2 responses (Zhu et al., 2006), the relevant DNAzymes are expected to be useful for the treatment of inflammatory skin diseases.

In the second approach we used the siRNA to $\beta 1$ integrin. Previous reports have indicated that siRNA has advantages over antisense oligonucleotides due to its greater resistance to nuclease degradation (Bertrand et al., 2002). Although it has a high specificity in gene silencing, there is a frequent off-target suppression of other genes resulting from partial complementarity (Jackson et a.l, 2003), immunostimulation of adverse effects (Sioud, 2006), and toxicity from interfering with endogenous microRNA pathway (Petrocca \& Lieberman, 2011). Hence, there is a need for further investigation and search for more efficient tools to control integrin-dependent cellular processes.

Comparing the levels of knockdown achieved by siRNA and DNAzymes is not an easy task, since the design rules for sequence and site selection, as well as optimal transfection conditions for both of them are different. Therefore, in our studies both inhibitors used under their optimal conditions, at which they displayed highest efficiency in blocking the $\beta 1$ expression in cancer cells without producing cytotoxic effects. Interestingly, siRNA $\beta 1$ appeared to be a slightly more capable inhibitor than $\beta 1 \mathrm{DE}$ when tested in vitro, however it was less effective in blocking the growth of tumors produced by PC3 cells. In vitro, even when used at much lower concentration than $\beta 1 \mathrm{DE}$, it produced the same or higher level of inhibition of the total $\beta 1$ synthesis, and more extended downregulation of the $\beta 1$ expression on cell surface expression in both types of cancer cells used. In contrast, intra-tumor administration of $\beta 1 \mathrm{DE}$ virtually terminated the tumor growth when both PC3 and HT29 cells were used to produce xenografts. Under the same conditions, siRNA $\beta 1$ hindered the tumor growth to a lesser extent when compared to $\beta 1 \mathrm{DE}$. Different efficiency in vivo may result rather from the lower stability of siRNA in extra- and intracellular compartments than from the distinctive duration of gene-silencing by both inhibitors. For proliferating tumor cells, gene-silencing produced by siRNA lasts for less than a week because of the dilution of siRNAs that occurs with each cell division as the RISC and the siRNAs bound to it get divided between daughter cells. In both xenograft models, the inhibition produced after a week since the administration of siRNA $\beta 1$ and $\beta 1 \mathrm{DE}$ equaled to $45.2 \%$ or $64.5 \%$ and $92.2 \%$ or $83.8 \%$ respectively, when the tumor growth of colon cancer or prostate cancer xenografts was tested. It suggests a significantly higher inhibitory efficiency of $\beta 1 \mathrm{DE}$ when compared to that of siRNA $\beta 1$ produced in xenografted mice.

Taking into consideration all collected data, our results confirm that siRNA and DNAzymes can effectively downregulate the $\beta 1$ integrin expression with great specificity at the protein synthesis level. The siRNA appears to be quantitatively more efficient with more durable effects in the cell culture, however, the DNAzyme produces more extensive inhibition of tumor growth during in vivo experiments.

\section{Acknowledgements}

This work was supported by the projects of the Polish Ministry of Science and Higher Education [N401 1217 33, N301 4392 38]; and by the Medical University of Lodz [502-03/6-098-01/502-64-006].

\section{REFERENCES}

Albelda SM (1993) Role of integrins and other cell adhesion molecules in tumor progression and metastasis. Lab Invest 68: 4-17.

Barnes PJ (2008) Role of GATA-3 in allergic diseases. Curr Mol Med 8: $330-334$. 
Bertrand JR, Pottier M, Vekris A, Opolon P, Maksimenko A, Malvy C (2002) Comparison of antisense oligonucleotides and siRNAs in cell culture and in vivo. Biochem Biophys Res Commun 296: 1000-1004.

Cieslak M, Niewiarowska J, Nawrot M, Koziolkiewicz M, Stec WJ, Cierniewski CS (2002) DNAzymes to $\beta 1$ and $\beta 3$ mRNA downregulate expression of the targeted integrins and inhibit endothelial cell capillary tube formation in fibrin and matrigel. J Biol Chem 277: 6779-6787.

Cieslak M, Szymanski J, Adamiak RW, Cierniewski, CS (2003) Structural rearrangements of the $10-23$ DNAzyme to $\beta 3$ integrin subunit mRNA induced by cations and their relations to the catalytic activity. J Biol Chem 278: 47987-47996.

Goel HL, Breen M, Zhang J, Das I, Aznavoorian-Cheshire S, Greenberg NM, Elgavish A, Languino LR (2005) $\beta 1 \mathrm{~A}$ integrin expression is required for type 1 insulin-like growth factor receptor mitogenic and transforming activities and localization to focal contacts. Cancer Res 65: 6692-6700.

Goel HL, Fornaro M, Moro L, Teider N, Rhim JS, King M, Languino LR (2004) Selective modulation of type 1 insulin-like growth factor receptor signaling and functions by $\beta 1$ integrins. J Cell Biol 166: 407-418.

Hannon GJ (2002) RNA interference. Nature 418: 244-251.

Holly SP, Larson MK Parise LV (2000) Multiple roles of integrins in cell motility. Exp Cell Res 261: 69-74.

Hynes RO (1992) Integrins: versatility, modulation, and signaling in cell adhesion. Cell 69: 11-25.

Isaka Y (2007) DNAzymes as potential therapeutic molecules. Curr Opin Mol Ther 9: 132-136.

Jackson AL, Bartz SR, Schelter ?., Kobayashi SV, Burchard J, Mao M, Li B, Cavet G, Linsley PS (2003) Expression profiling reveals offtarget gene regulation by RNAi. Nat Biotechnol 21: 635-637.

Kohlgraf KG, Gawron AJ, Higashi M, Meza JL, Burdick MD, Kitajima S, Kelly DL, Caffrey TC, Hollingsworth MA (2003) Contribution of the MUC1 tandem repeat and cytoplasmic tail to invasive and metastatic properties of a pancreatic cancer cell line. Cancer Res 63: 5011-5020.

Ma WW, Adjei AA (2009) Novel agents on the horizon for cancer therapy. CA Cancer J Clin 59: 111-137.

Manes T, Zheng DQ, Tognin S, Woodard AS, Marchisio PC, Languino LR (2003) Alpha(v)beta3 integrin expression up-regulates cdc2, which modulates cell migration. J Cell Biol 161: 817-826.

Mukherjee P. Tinder TL, Basu GD, Gendler SJ (2005) MUC1 (CD227) interacts with lck tyrosine kinase in Jurkat lymphoma cells and normal T cells. J Leukoc Biol 77: 90-99.

Niewiarowska J, Sacewicz I, Wiktorska M, Wysocki T, Stasikowska O, Wagrowska-Danilewicz M, Cierniewski CS (2009) DNAzymes to mouse beta1 integrin mRNA in vivo: targeting the tumor vasculature and retarding cancer growth. Cancer Gene Ther 16: 713-22.

Petrocca F, Lieberman J (2011) Promise and challenge of RNA interference-based therapy for cancer. J Clin Oncol 29: 747-754.
Pignatelli M, Hanby AM, Stamp GW (1991) Low expression of $\beta 1, \alpha 2$ and $\alpha 3$ subunits of VLA integrins in malignant mammary tumours. J Pathol 165: 25-32.

Rathinam R, Alahari SK (2010) Important role of integrins in the cancer biology. Cancer Metastasis Rev 29: 223-237.

Ren J, Agata N, Chen D, Li Y, Yu WH, Huang L, Raina D, Chen W, Kharbanda S, Kufe D (2004) Human MUC1 carcinoma-associated protein confers resistance to genotoxic anticancer agents. Cancer Cell 5: $163-175$.

Santoro SW, Joyce GF (1998) Mechanism and utility of an RNA-cleaving DNA enzyme. Biochemistry 37: 13330-13342.

Schiffelers RM, Woodle MC, Scaria P (2004) Pharmaceutical prospects for RNA interference. Pharm Res 21: 1-7.

Schubert S, Gul DC, Grunert HP, Zeichhardt H, Erdmann VA, Kurreck J (2003) RNA cleaving '10-23' DNAzymes with enhanced stability and activity. Nucleic Acids Res 31: 5982-5992.

Schubert S, Kurreck J (2004) Ribozyme and deoxyribozyme strategies for medical applications. Curr Drug Targets 5: 667-681.

Sel M, Wegmann T, Dicke S, Sel W, Henke AO, Yildirim H, Renz H, Garn H (2008) Effective prevention and therapy of experimental allergic asthma using a GATA-3-specific DNAzyme. J Allergy Clin Immunol 121: 910-916.

Silverman SK (2005) In vitro selection, characterization, and application of deoxyribozymes that cleave RNA. Nucleic Acids Res 33: 61516163.

Sioud M (2006) Innate sensing of self and non-self RNAs by toll-like receptors. Trends Mol Med 12: 167-176.

Tritz R, Habita C, Robbins JM, Gomez GG, Kruse CA (2005) Catalytic nucleic acid enzymes for the study and development of therapies in the central nervous system: review article. Gene Ther Mol Biol 9A: 89-106.

Uhm JH, Gladson CL, Rao JS (1999) The role of integrins in the malignant phenotype of gliomas. Front Biosci 4D: 188-199.

Wiktorska M, Papiewska-Pajak I, Okruszek A, Sacewicz-Hofman I, Niewiarowska J (2010) DNAzyme as an efficient tool to modulate invasiveness of human carcinoma cells. Acta Biochim Polon 57: 269-275.

Yazji S, Bokowski R, Kondagunta V, Figlin R (2007) Final results from phase II study of volociximab, an $\alpha 5 \beta 1$ anti-integrin antibody, in refractory or relapsed metastatic clear cell renal cell carcinoma (mCCRCC). J Clin Oncol 18S (Suppl): 5094 (abstract).

Zhu J, Yamane H, Cote-Sierra J, Guo L, Paul WE (2006) GATA-3 promotes Th2 responses through three different mechanisms: induction of Th2 cytokine production, selective growth of Th2 cells and inhibition of Th1 cell-specific factors. Cell Res 16: 3-10.

Zutter MM, Mazoujian G, Santoro SA (1990) Decreased expression of integrin adhesive protein receptors in adenocarcinoma of the breast. Am J Pathol 137: 863-870. 